\title{
Ankara İlinde Un Fabrikalarının Buğday Alım Kriterleri, Üretim ve Pazarlama Yapıları
}

\author{
${ }^{*}$ Rahmi TAȘCI ${ }^{1}$, Sevinç KARABAK ${ }^{1}$, Merve BOLAT ${ }^{1}$, Aliye PEHLIVAN², \\ Turgay ȘANAL², Oğuz ACAR², Seda KÜLEN², \\ Erdoğan GÜNEȘ ${ }^{3}$, Mevhibe ALBAYRAK ${ }^{3}$
}

${ }^{1}$ Tarla Bitkileri Merkez Araștırma Enstitüsü, Tarım Ekonomisi Bölümü, Ankara, Türkiye ${ }^{2}$ Tarla Bitkileri Merkez Araștırma Enstitüsü, Kalite Değerlendirme ve Gıda Bölümü, Ankara, Türkiye ${ }^{3}$ Ankara Üniversitesi Ziraat Fakültesi, Tarım Ekonomisi Bölümü, Ankara, Türkiye

${ }^{*}$ Corresponding author e-mail (Sorumlu yazar e-posta): tasci@tarimorman.gov.tr

Öz

Bu çalıșmada; Ankara ilinde faaliyet gösteren un fabrikalarının buğday satın alımına etki eden kriterlerin, un üretim ve pazarlama yapılarının ortaya konulması amaçlanmıștır. Ankara ilinde faaliyet gösteren 30 un fabrikası ile tam sayım yöntemine göre gerçekleștirilen anket verileri değerlendirilmiștir. Anket çalıșmaları 2015 yılında tamamlanmıștır. Araștırma sonucunda; un fabrikalarının buğday alıș fiyatını belirlemede en önemli kriter buğdayın süne emgi oranı olmuș, fiyata etki eden diğer kriterler sırasıyla; buğdayın çeșidi, enerji değeri, gluten değeri, protein değeri ve hektolitresi olarak tespit edilmiștir. Un fabrikalarının \%23,3'ünün süne emgi oranı \%1'e kadar, \%16,7'sinin süne emgi oranı \%2'ye kadar olan buğdayları satın aldığı, \%16,6'sının ise süne emgi oranını dikkate almadan tüm buğdayları satın aldığı tespit edilmiștir. Ankara'daki un fabrikalarında ișlenen 39 farklı buğday çeșidi kaydedilmiș olup, un fabrikalarının \%63,3'ünde piyasada kalite kriterleri birbirine benzeyen çok sayıda buğday çeșidi mevcut olduğundan - yeni bir çeșidi denemek yerine, uzun yıllardır kullandıkları ve kalite kriterlerini bildikleri çeșitleri kullanmayı tercih ettikleri belirlenmiștir. Buğdaydaki süne emgi oranının; un fabrikaları için buğday satın almada fiyata etki eden en önemli kriter olarak ön plana çıktığı için, bu durumun buğdayın protein kalitesine ve daha çok buğday çeșidinin genetik yapısına bağlı olduğundan, protein kalitesi yüksek çeșitlerin un sanayi tarafından öncelikle tercih edildiği ve daha yüksek fiyatla ișlem gördüğü belirlenmiștir. Bu sonuca bağlı olarak, süne mücadelesi ile ilgili çiftçi eğitimlerinin ve saha çalıșmalarının artarak devam ettirilmesinin, buğday üreticileri ve fabrikalar açısından daha da önem kazandığı ortaya konulmuștur.

Anahtar Kelimeler: Un fabrikası, buğday, un, süne, Ankara

\section{Wheat Purchase Criteria, Production and Marketing Structures of Flour Factories in Ankara Province}

\section{Abstract}

In this study, it is aimed to reveal the criteria affecting the wheat purchase on flour production and marketing structures of flour mills operating in Ankara. The survey data obtained from 30 flour mills operating in Ankara were used which got according to the complete counting method. Surveys were completed in 2015. According the result of study, the most important criterion in determining wheat buying price was sunn bug damage ratio while the other criteria affecting wheat were determined as wheat variety, energy value, gluten value, protein value and hectoliter. It was determined that $23.3 \%$ of the flour mills purchased wheat with the rate of absorbance up to $1 \%, 16.7 \%$ of them absorbed to the rate of $2 \%$, while $16.6 \%$ of them purchased all wheat regardless of the rate of sunn bug damage ratio. It had been identified that there are 39 different wheat varieties processed in flour mills in Ankara and $63.3 \%$ of flour mills preferred to use the similar varieties with known quality criteria and have been used them for many years instead of trying a new variety. Since the ratio of sunn bug damage in the wheat is the most important criterion that affect the price on the wheat purchase, and that this is due to the protein quality of the wheat and the genetic structure of the wheat variety. It has been determined that varieties that have highest protein quality are preferred by the industry and processed at higher prices. Based on this result, it has been revealed that increasing the continuity of farmer training and fieldwork related to the struggle for sunn bug is more important in terms of wheat producers and industrialists.

Keywords: Flour factory, wheat, flour, sunn bug, Ankara 


\section{Giriș}

ünyada gıda güvenliği, güvenilirliği, kendine yeterlilik ve sürdürülebilirlik kavramlarının kullanımının artmasıyla, stratejik ürünlerde yapılan araștırmalar da çoğalmıştır. Temel intiyaç maddesi olan ve Türkiye için stratejik ürünlerden biri olan buğday, ana besin kaynağı olmasının yanı sıra, tarımsal ve ekonomik açıdan da önemli bir sektör olma özelliğini devam ettirmektedir. Yapılan ıslah araștırmaları, birçok buğday çeșidinin geliștirilmesine katkıda bulunmuș olup, bunlar tarımsal ișletmelerin kullanımına sunulmuștur. Ancak mevcut çeșitlerin üretici ve fabrika tarafından kullanılması ve yayılmasında özellikle sektörün kendi içinde çeșit algısı ve tercihlerinin etkili olduğu görülmektedir.

Üretici, yeni geliștirilen ve piyasaya sunulan çeșitleri takip etmeye çalıșmakta ve mevcut çeșitlerden daha kaliteli ve özellikle verim potansiyeli yüksek olan çeșitlere doğru yönelmektedir. Ancak üretici istekleri ve fabrikaların istekleri birbirine uyum sağlayamamakta ve un fabrikası kaliteyi, buğday üreticisi ise öncelikli olarak verimi ön plana çıkarmaktadır. Hem fabrikanın hem de üreticinin isteklerini karșılayabilmek amacıyla, yeni çeșit geliștirme çalıșmalarında buğdayın kalite değerlerinin yanında veriminin de yüksek olması hedeflenmektedir. Geliștirilen her bir buğday çeșidinin piyasada kendine yer bulabilmesi ve üretim için tercih edilmesinde etkili faktörler bulunmaktadır. $\mathrm{Bu}$ faktörler, uygulanan tarım politikaları, tohum alıș ve buğday satıș fiyatı, iklim, ekoloji ve pazarlama yapısına bağlı olarak değișiklik gösterebilmektedir. Yapılan ıslah çalıșmalarının uygulamadaki bașarısı her ne kadar ıslah materyaline bağlı olsa da pazar koșulları ve üretici davranıșları, tercihin olușmasında ve fiyatın belirlenmesinde önemli rol oynamaktadır. Üretilen un, ekmek, makarna ve bisküvide kalite standartlarına uyma zorunluluğu, özellikle ihracat yapan firmalar için önem kazanmaktadır. Standart üretimin gerekliliği, fabrikaların yatıım ve hammadde de seçici olmasını gerekli kılmaktadır. İstenilen kalite ve çeșitte ürün imal etmek için, un sanayinin ihtiyacına uygun buğdaya, fırıncıların una ve tüketicinin ise isteğine uygun ekmeğe intiyacı bulunmaktadır.
Türkiye'de teknik ve ekonomik yönden buğday, un ve unlu mamuller üretimi yapan ișletmeler ile ilgili olarak yapılan çalıșmalar incelenmiș olup, (Albayrak ve Birsin, 2012; Arıkbay,1993; Bayramoğlu, 2007; Bostancı ve ark., 1999; Cemalcılar,1982; Cörüt, 1982; Çoban, 2003; Eker, 2007; Ekși ve ark., 2005; Günalp ve ark., 2002, Güneș, 1999; Karakuș, 2017; Karkacıer, 2001; Küçükçongar, 2001; Kızıloğlu, 2004; Marasalı ve Karlı, 2005; Özdemir, 2005; Rehber, 1997; Tașcı ve ark., 2017; Tașcı ve Bayramoğlu, 2017) Ankara ilinde un sektörünün, buğday alım kriterleri ve buğday çeșitlerinin un sanayinde kullanım durumu ve pazarlama yapısını araștıran güncel çalıșmalara rastlanıımamıștır. Ayrıca buğday çeșitlerinin un sektöründe tercih durumlarını ortaya koyan ve un sanayii ile ekmek fırınları arasındaki hammadde alıșverișini hedefleyen araștırmaların oldukça yetersiz olduğu görülmüștür. Buğday üretimi yapan üreticilerin, son yıllarda buğdayı pazarlamasındaki kısıtların en bașında buğdayın kalitesi gelmektedir. Burnett ve Clarke (2002), buğday pazarında kalitenin önemine dikkat çekmiș, kritik kalite kriteri olarak tanımladığı tane protein oranının en az \%12 olması gerektiğini, ayrıca çeșit özelliği, üründe tane iriliği yönünden homojenliğin ve 1000 tane ağırlığının da önemli olduğunu bildirmișlerdir. Buğdayda kaliteyi olușturan fiziksel, kimyasal ve teknolojik özellikler üzerinde iklim ve toprak gibi çevre koșulları ve yetiștirme teknikleri yanında, genotipik etkinin de (Otteson ve ark., 2008) oldukça önemli-olduğu kaydedilmiștir.

$\mathrm{Bu}$ sebeple; sanayinin buğday satın alma tercihlerindeki kriterlerinin doğru tespit edilmesi ve sonuçların ıslahçılara ve üreticilere aktarılması önem kazanmaktadır.

\section{Materyal ve Yöntem}

Türkiye Un Sanayicileri Federasyonu kayıtları ve Ankara Tarım ve Orman IIı Müdürlüğü verilerine göre Ankara ilinde faaliyet gösteren un fabrikaları ile tam sayım yöntemine göre anket çalıșması gerçekleștirilmiștir. Anketler, 2015 yılı Mayıs ve Kasım aylarında tamamlanmıștır. Ankara'da faaliyet gösteren un fabrikalarının \%33,3'ü Polatlı İlçesinde, \%13,3'ü Sincan 
Çizelge 1. Un fabrikalarının ilçelere göre dağılımı

Table 1. Distribution of flour factories in different districts (piece and \%)

\begin{tabular}{llccllcc}
\hline Sıra No & İlçe adı & Adet & Oran (\%) & Sıra No & İlçe adı & Adet & Oran (\%) \\
\hline 1 & Polatı & 10 & 33.3 & 8 & Akyurt & 1 & 3.3 \\
2 & Sincan & 4 & 13.3 & 9 & Gölbașı & 1 & 3.3 \\
3 & Çubuk & 3 & 10.0 & 10 & Kalecik & 1 & 3.3 \\
4 & Bala & 2 & 6.7 & 11 & Kazan & 1 & 3.3 \\
5 & Beypazarı & 2 & 6.7 & 12 & Nallıhan & 1 & 3.3 \\
6 & Güdül & 2 & 6.7 & Toplam & & 30 & 100.0 \\
7 & Haymana & 2 & 6.7 & & & & \\
\hline
\end{tabular}

Organize Sanayi Bölgesinde ve \%10'u ise Çubuk İlçesinde faaliyet göstermektedir. Anket çalıșması yapılan un fabrikalarının ilçelere göre oransal dağılımı Çizelge 1'de gösterilmiștir.

Anket sonuçlarından elde edilen veriler tanımlayıcı istatistikler ve Likert ölçeği kullanılarak değerlendirilmiștir.

\section{Bulgular ve Tartıșma}

Un fabrikalarının birinci tercihleri arasında sadece üç buğday çeșidi bulunmaktadır. Bu çeșitler \%39,3 Esperia, \%32,1 Tosunbey ve $\% 28,6$ oranı ile Bezostaja 1 olarak sıralanmaktadır. Un fabrikalarının ikinci tercihleri oransal olarak sıralandığında; Esperia, Tosunbey ve Bezostaja 1, Ukrayna (popülasyon), Bayraktar 2000, Quality ve Flamura 85 çeșitlerinin tercih edildiği görülmektedir. Üçüncü tercihler içinde Esperia, Tosunbey ve Bezostaja 1 bulunurken, $\% 4,2$ oranında makarnalık buğday çeșitleri ve $\% 4,2$ oranında $\% 2-3$ süne emgili buğday çeșitlerinin de tercih edildiği görülmektedir. Belirtilen buğday çeșitleri dıșında düșük oranda da olsa Sagittario, Altay 2000, Kağanbey, Pamukova 97, Panda ve Osmaniye ve makarnalık çeșitlerden Eminbey, Kızıltan 91 gibi çeșitler de fabrikalar tarafından tercih edildiği belirlenmiștir (Çizelge 2).

Un fabrikalarının görüșleri doğrultusunda, buğday çeșitlerinin tercihindeki en önemli kriterler çeșitlere göre; Esperia'nın çok yüksek oranda enerjisi içermesi, Bezostaja 1'in protein değerlerinin yüksek olması ve Tosunbey çeșidinin enerji değerinin yüksek olmasıdır. Un fabrikalarının daha önceki yıllarda kullandıkları fakat artık bazı kalite değerlerinden dolayı kullanımdan vazgeçtikleri buğday çeșitleri; Kate A-1, Gerek 79, Kunduru 1149, Pehlivan ve Demir 2000 Kransukovski, Bereket, Selimiye, Konya 2002 olarak sıralanmıștır. Un sanayinin bu çeșitleri tercih etmeme nedenlerinin bașinda, un verimlerinin ve protein kalitelerinin düșük olması gelmektedir. Belirtilen hektolitresi düșük, ufak taneli, kabuğu kalın, kepeği çok vb. olumsuz tanımlamalar bu çeșitlerin un verimlerinin düșük olmasına sebep olmaktadır. Un fabrikaları tarafından bu çeșitlerin enerjisi düșük, indeksi düşük, direnci düşük, ekstensograf değeri düșük, zayıf, kalitesi düșük tanımlamaları ve protein kalitelerinin (gluten kalitesi) iyi olmadığı aktarılmıștır. Yeni un tebliğinde unda kül miktarı arttırılığından, kaliteli ekmek üretilebilmesi için, un fabrikalarının daha kaliteli un üretmeleri ve dolayısıyla protein kalitesi daha yüksek buğday kullanmaları gerekmektedir. Un fabrikalarının 2014 yılında fabrikalarında kullandıkları buğday çeșitlerinden Esperia $\% 27,1$ ile en fazla kullanılan buğday çeșidi olurken, Bezostaja 1 çeşidi \%21 ile ikinci sırada, Tosunbey çeșidi ise \%19,7 ile üçüncü sırada yer almıștır. Öne çıkan bu çeşitlerin yanı sıra $\% 8,4$ oranında ithal buğdaylar, $\% 4,7$ oranında ise makarnalık buğday çeșitleri kullanılmıștır (Çizelge 3).

Ankara' da faaliyet gösteren un fabrikalarının $\% 56,7$ 'si- her yıl ithal buğday kullanmaktadır. Fabrikaların \%58,8'i yurt içinden düzenli olarak standart kalitede buğday temin edemediğinden dolayı, \%23,5'i ise ithal buğdayların yurt içinden sağlanan buğdaya göre daha az maliyetli olması nedeniyle tercih etmektedir. Un fabrikalarının tedarik kaynakları içerisinde üreticiler $\% 45,3$ oran ile ilk sırada bulunurken, 
Çizelge 2. Un fabrikalarının buğday çeșitlerindeki tercih sıralaması

Table 2. The order of preferences in wheat varieties by flour factories

\begin{tabular}{|c|c|c|c|c|c|}
\hline Sıra No & Buğday Çeșidi & $\begin{array}{c}\text { 1.Tercih } \\
\%\end{array}$ & $\begin{array}{c}\text { 2. Tercih } \\
\%\end{array}$ & $\begin{array}{c}\text { 3. Tercih } \\
\%\end{array}$ & $\begin{array}{c}\text { 4. Tercih } \\
\%\end{array}$ \\
\hline 1 & Esperia & 39.3 & 22.2 & 12.5 & 11.1 \\
\hline 2 & Tosunbey & 32.1 & 37.0 & 12.5 & 5.6 \\
\hline 3 & Bezostaja 1 & 28.6 & 14.8 & 29.1 & 27.6 \\
\hline 4 & Ukrayna & & 11.1 & 16.5 & 11.1 \\
\hline 5 & Bayraktar 2000 & & 7.5 & & \\
\hline 6 & Quality & & 3.7 & & 11.1 \\
\hline 7 & Flamura-85 & & 3.7 & & \\
\hline 8 & Aldane & & & 4.2 & \\
\hline 9 & Renan & & & 4.2 & \\
\hline 10 & Syrena odes'ka & & & 4.2 & \\
\hline 11 & ТT601 & & & 4.2 & \\
\hline 12 & Gerek 79 & & & 4.2 & 5.6 \\
\hline 13 & Adana 99 & & & & 5.6 \\
\hline 14 & Kate A-1 & & & & 5.6 \\
\hline 15 & Krasunia odes'ka & & & & 11.1 \\
\hline 16 & Ahmetağa & & & & \\
\hline 17 & Ceyhan 99 & & & & \\
\hline 18 & Kunduru 1149 & & & & 5.6 \\
\hline 19 & \%2-3 süneli ekmeklik buğday & & & 4.2 & \\
\hline 20 & Makarnalık buğdaylar & & & 4.2 & \\
\hline Toplam & & 100.0 & 100.0 & 100.0 & 100.0 \\
\hline
\end{tabular}

borsa \%30,3 ile ikinci sırada yer almaktadır. Özellikle Ankara'daki un fabrikalarının 1/3'ünün Polatlı ilçesinde faaliyet göstermesi ve Polatı'da Ticaret Borsası'nın bulunması,

Çizelge 3. Un fabrikalarında kullanılan buğday çeșitleri (2014)

Table 3. The wheat species used the flour factories (2014)

\begin{tabular}{lc}
\hline Buğday Çeșitleri & Oran (\%) \\
\hline Esperia & 27.1 \\
Bezostaja 1 & 21.0 \\
Tosunbey & 19.7 \\
Adana 99 & 1.7 \\
Bayraktar 2000 & 1.3 \\
Diğer ekmeklik buğday çeșitleri & 16.1 \\
İthal buğday & 8.4 \\
Makarnalık buğday çeșitleri & 4.7 \\
\hline Toplam & 100.0 \\
\hline
\end{tabular}

un fabrikalarının buğday alım tercihlerinde önemli bir rol üstlenmektedir. Toprak Mahsulleri Ofisi'nden buğday tedarik miktarı ise beklenilenin altında $(\% 3,4)$ olup, bunun da tamamı ithal buğdaydır. (Çizelge 4). Ekmeklik un üreten fabrikalar içinde sözleșmeli buğday üretimi yapan fabrika bulunmamaktadır. Sadece bisküvi üreten un fabrikaları sözleșmeli buğday alımı yapmaktadır. Rusya, Kazakistan, Litvanya ve Sibirya'dan buğday ithalatı yapılırken, fabrikaların sadece \%0,1'i kendi ișlediği unu kendisi üretmektedir.

Un fabrikalarının buğday alımlarında fiyata etki eden kriterlere (çok önemsizden, çok önemliye doğru (1-5 skalası) üzerinden en yüksek puan 5 olacak șekilde) puan verilmiș ve puanların ağırlıklı ortalaması alınarak bir skala elde edilmiștir. Bu değerlendirme sonucunda; 4,67 puan ile en önemli kriter buğdayın süne emgi oranı olarak belirlenmiștir. 4,55 puan ile ikinci önemli kriter buğdayın çeșidi 
Çizelge 4. Un fabrikalarının buğday tedarik kaynakları

Table 4. The wheat supply chains of the flour factories

\begin{tabular}{llc}
\hline Sıra No & Buğday Tedarik Kaynakları & Oran (\%) \\
\hline 1 & Üretici & 45.3 \\
2 & Borsa & 30.3 \\
3 & Tüccar & 12.6 \\
4 & İthal & 8.6 \\
5 & TMO & 3.4 \\
6 & Kendi üretimi & 0.1 \\
\hline Toplam & & 100.0 \\
\hline
\end{tabular}

olarak belirlenirken, 4,50 oranı ile buğdayın enerji değeri üçüncü en önemli kriter olarak belirlenmiştir (Şekil 1).

Buğdayın protein kalitesi daha çok çeșidin genetik yapısına bağııdır, bu sebeple protein kalitesi yüksek çeșitler un sanayi tarafından öncelikle tercih edilmektedir. Protein kalitesi yüksek çeșitler daha yüksek fiyatlarla ișlem görmektedir. Un fabrikalarının sahipleri veya sorumlu teknik elemanlarının \%87,0'si ișletmelerine ziyaret amaçlı veya buğday satmak amacıyla gelen üreticilere çeșit tavsiyesi yapmaktadır. Buğday üreticilerine un fabrikaları tarafından yetiștirilmesi tavsiye edilen buğday çeșitlerinin bașında \%48,1 oranı ile Esperia gelirken, ikinci sırada \%25,9 ile Tosunbey çeșidi gelmektedir. Tavsiye edilen bu çeșitler, protein değeri yüksek olan çeșitlerdir. Bezostaja 1 ise un fabrikalarında ikinci sırada kullanılmasına rağmen, un fabrikalarının tavsiye ettiği çeșitler arasında $\% 6,3$ oranı ile son sıralarda yer almaktadır. Toprak Mahsulleri Ofisi (TMO) 2011 yilından itibaren buğday alımlarında protein miktarına göre değerlendirme yapmaya bașlamıștır. Bu durumun etkisi sorulduğunda \%33,3'ü iyi ve yerinde bir uygulama olduğunu, \%30,0'u TMO ile bir alıșverișlerinin olmadığını ve \%13,3'ü un sanayine bir etkisinin olmadığını belirtmiștir. Etkisi olmadığını belirtenlerin kalite kriterlerine göre alım yaptıkları düşünülmektedir. TMO'nun buğday alım kriterlerine sünenin etkisinin de eklenmesini isteyen \%10 oranında ișletmenin, TMO'nun yeni uygulamasından yeterince haberdar olmadığı ancak TMO'nun 2015 yılında ekmeklik buğdayda süne tahribatı ve protein oranına göre ilave fiyat uygulamasının ișletmeler tarafından sonraki yıllarda olumlu etkisinin fark edileceği düșünülmektedir (Çizelge 5).

Un fabrikalarının \%63,3'ü piyasada kalite kriterleri birbirine benzeyen çok sayıda buğday çeșidi mevcut olduğunu, bu kadar fazla çeșidi takip edemediklerini belirtirken, yeni bir çeșidi denemek yerine uzun yıllardır kullandıkları

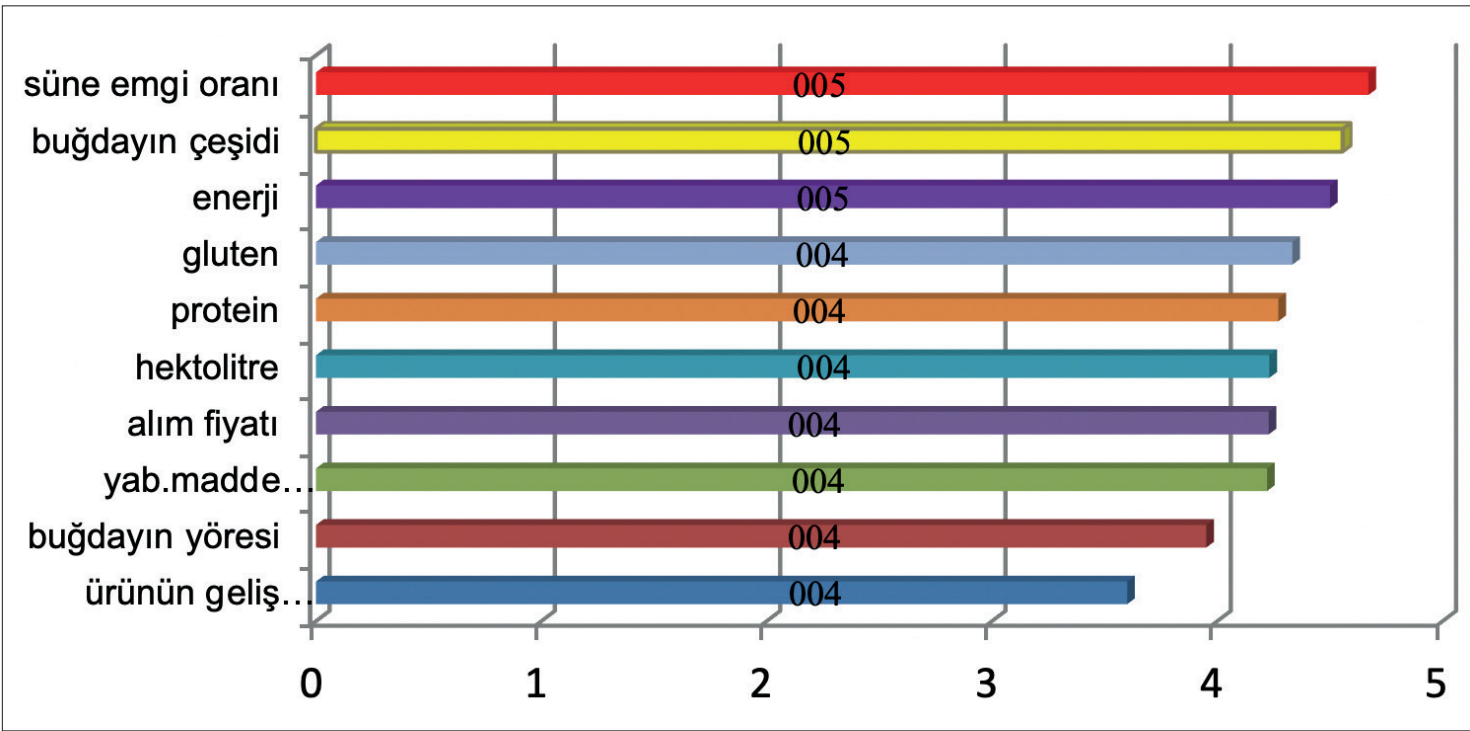

Șekil 1. Un sanayisinin buğday alıs fiyatı belirleme kriterleri ( 1 çok önemsiz / 5 çok önemli )

Figure 1. The price determination criteria of the flour industries for wheat purchasing (1 unimportant / 5 very important) 
Çizelge 5. Un fabrikalarının TMO'nun protein miktarına göre buğday alımı yapması hakkındaki görüșleri Table 5. The opinions of the flour factories about purchasing of wheat according to protein content by TMO

\begin{tabular}{lcc}
\hline Un Fabrikalarının TMO'nun Buğday Alım Kriterlerine Bakıșı & Frekans & Oran (\%) \\
\hline İyi ve yerinde bir uygulama oldu & 10 & 33.3 \\
TMO ile ürün alıșverișimiz yok & 9 & 30.0 \\
Un fabrikalarına etkisi olmadı & 4 & 13.3 \\
Sadece proteine göre alım yeterli değil, süne kriteri de eklensin & 3 & 10.0 \\
Sadece proteine göre alım yeterli değil, buğday çeșitlerine göre alım kriteri de & 3 & 10.0 \\
eklensin & & 3.3 \\
Fikrim yok & 1 & 100.0 \\
\hline Toplam & 30 & 2 \\
\hline
\end{tabular}

ve kalite kriterlerini bildikleri çeșitleri kullandıklarını belirtmektedir. Yeni çeșitlerin geliștirilmesinden ziyade, eldekimevcutbuğday çeșitlerinin korunması gerektiğini ve üreticiler arasında ekilișinin yaygınlaștırılmasını talep etmektedirler. Fabrikaların \%30'u, Türkiye'deki buğday çeşidi geliştirme çalışmalarına olumlu bakarken daha çok çeşidin olması gerektiğini ifade etmektedir. Geriye kalan \%6,7'si ise bu konuda fikirlerinin olmadığını belirtmișlerdir. Un fabrikaları için buğday alımında fiyata etki eden en önemli kriter, süne emgi oranı olarak belirlenmiștir. \%23,3'ü süne emgi oranı \%1'e kadar olan buğdayları satın aldığını ifade ederken, \%16,7'si süne emgi oranı \%2'ye kadar olan buğdayları, \%16,6'sı ise süne emgi oranı ne olursa olsun tüm buğdayları satın aldıklarını belirtmiștir (Çizelge 6).

Çizelge 6. Un fabrikalarının satın aldığı buğdayın süne emgi oranlarına göre üst limitleri

Table 6. The maximum limits of proportion of wheat which the flour factories purchased was damaged by sunn pest

\begin{tabular}{lcc}
\hline $\begin{array}{l}\text { Süne Emgi Oranı } \\
\text { Üst Limiti (\%) }\end{array}$ & Frekans & $\begin{array}{c}\text { Alım Oranları } \\
(\%)\end{array}$ \\
\hline 1.0 & 7 & 23.3 \\
1.5 & 2 & 6.7 \\
2.0 & 5 & 16.7 \\
2.5 & 2 & 6.7 \\
3.0 & 6 & 20.0 \\
3.5 & 3 & 10.0 \\
Hepsini alırım & 5 & 16.6 \\
\hline Toplam & 30 & 100.0 \\
\hline
\end{tabular}

Köksel ve ark.'nın (2000) belirttiği üzere, süne/kımıl zararının buğdayın ekmeklik kalitesini bozmasının başlıca nedeni, bu zararlının buğdayı emerek beslenmesi sırasında taneye bıraktığı sindirim salgılarında bulunan proteaz enzimleridir. Bu proteaz enzimi, süne/kımıl emgili taneler öğütüldüğünde una karıșır ve unda su içeriğinin düșük olması sonucu herhangi bir etki göstermez. Enzimin aktif hale geçip faaliyet gösterebilmesi için ortamın nem ve sıcaklığının uygun olması ve belli bir süre geçmesi gerekmektedir. Gluten proteinlerinin hidrolize olması sonucu hamur yumușamakta, yoğurma ve șekil verme sırasında elastikiyeti azalmakta, elde ve makinada ișlenmesi güçleșmekte ve fermantasyonda gaz tutma kapasitesi düșerek ekmeğin kabarması engellenmektedir.

Un fabrikaları için buğdaydaki süne emgi oranına göre satın almadaki fiyatlandırma ile ilgili örnek Çizelge 7'de gösterilmiștir. Süne emgi oranı \%2,0 olan bir buğday 1.00 TL/ kg satın alınırken, süne emgi oranı \%2,5'a çıktığında fiyat $0.80 \mathrm{TL} / \mathrm{kg}$ 'a düșmektedir. Bu örnekleme buğday çeșidinden bağımsız olarak yapılmaktadır.

(Dizlek ve İslamoğlu'nun (2010) belirttiği üzere süne emgi zararı, buğdayda kaliteyi etkileyen önemli faktörlerden birisidir. Süne tarafından beslenirken taneye bırakılan proteolitik ve amilolitik enzimler, un ürüne ișlenirken tekrar faaliyete geçmekte ve proteini parçalamaktadır. Emgili tane oranının belli bir oranın üzerinde olduğu unlardan yapılan ekmek hamuru; yumușak, cıvık, akıcı ve gaz tutma kapasitesi az olmaktadır. Buğdayda 
Çizelge 7. Un fabrikalarının süneli buğday alım fiyatlandırması örneği (2014)

Table 7. Example of the purchasing price of wheat with sunn pest of flour factories

\begin{tabular}{lc}
\hline Süne Emgi Oranı (\%) & Buğday Alım Fiyatı (TL/kg) \\
\hline 2,0 & 1.00 \\
2,5 & 0.80 \\
$2,5-3,5$ & 0.78 \\
\hline
\end{tabular}

protein oranının yüksek olması süne emgi zararının etkisini azaltabilmektedir. Gluten miktarının hem yüksek olması hem de kaliteli olması istenir. Tarla Bitkileri Merkez Araștırma Enstitüsü tarafından 2009 yılında tamamlanan Ülkesel Süne Projesinde çeșitlerin sahip oldukları protein kalitesine göre süne emgi zararından farklı derecede etkilendiği belirlenmiștir (TKB 2009). Bu çalıșmadan elde edilen çıktılara göre protein kalitesi iyi olan çeșitler \%5-6 emgili tane içermeleri durumunda bile kalitelerini çok bozmazken, düșük protein kalitesine sahip çeșitler \%1-2 emgili tane oranında sahip oldukları kaliteleri bozulmakta ve ișlenememektedir. Un fabrikaları da buğday çeșitlerinin protein kaliteleri hakkında bilgi sahibi olduklarından alım politikalarında süne emgi oranlarını çeșitlere göre farklı değerlendirmektedirler. Kate A 1, Pehlivan vb. protein kalitesi düșük çeșitlerde \%1 emgi oranını istemezken Esperia, Tosunbey, vb. protein kalitesi yüksek çeșitlerde \%3 emgi oranındakileri satın alabilmektedirler.
Ankara'daki un fabrikalarında ișlenen 39 farklı buğday çeșidi tespit edilmiștir. Bu buğday çeșitleri șunlardır:

Bezostaja 1, Tosunbey, Ukrayna, Krasunia odes'ka, Pehlivan, Demir 2000, Gün 91, Iikizce, Bayraktar 2000, Eser, Aldane, Lütfibey, Ahmetağa, Quality, Kate A-1, Zenit, Adana 99, Sagittario, Flamura-85, Konya 2002, Toros, Cömert 2, Svevo, Rumeli, Syrena Odes'ka, Kağanbey, Dariel, Pamukova 97, Iridium, Ceyhan 99, Negev, Nota, Kunduru 1149, Eminbey, Ankara 98, Çeșit 1252, Kızıltan 91'dir. $\mathrm{Bu}$ buğday çeșitlerinden; Kunduru 1149, Ankara 98, Çeșit 1252, Kızıltan 91, Zenit, Adana 99, Sagittario, Flamura-85, Konya 2002, Toros, Cömert 2, Svevo, Rumeli, Syrina odes'ka, Kağanbey, Eminbey, Dariel, Pamukova 97, iridium, Ceyhan 99, Negev, Nota çeșitleri sadece bir veya iki un fabrikası tarafından kullanılmakta oldukları ve genel olarak tercih edilen çeșitler arasında olmadıkları görülmüștür.

Bu çeșitlerin fabrikalar tarafından tanınırlığı, kullanım durumu ve kaliteleri hakkındaki görüșleri skala değerleri üzerinden ölçülmüștür. Skala çizelgesi üzerinde sol sütunda sıralanan buğday çeșitlerinin; fabrikalar tarafından tanınırlığı, kullanım durumu ve kullanılan çeșidin kendi amaçları doğrultusundaki performansları puanlandırılmıștır. Verilen puanların ağırlıklı ortalaması alınarak Șekil 2'de gösterilen grafik oluşturulmuştur. Un fabrikalarının en yüksek 5 (beș) olacak șekilde verdikleri puanlar

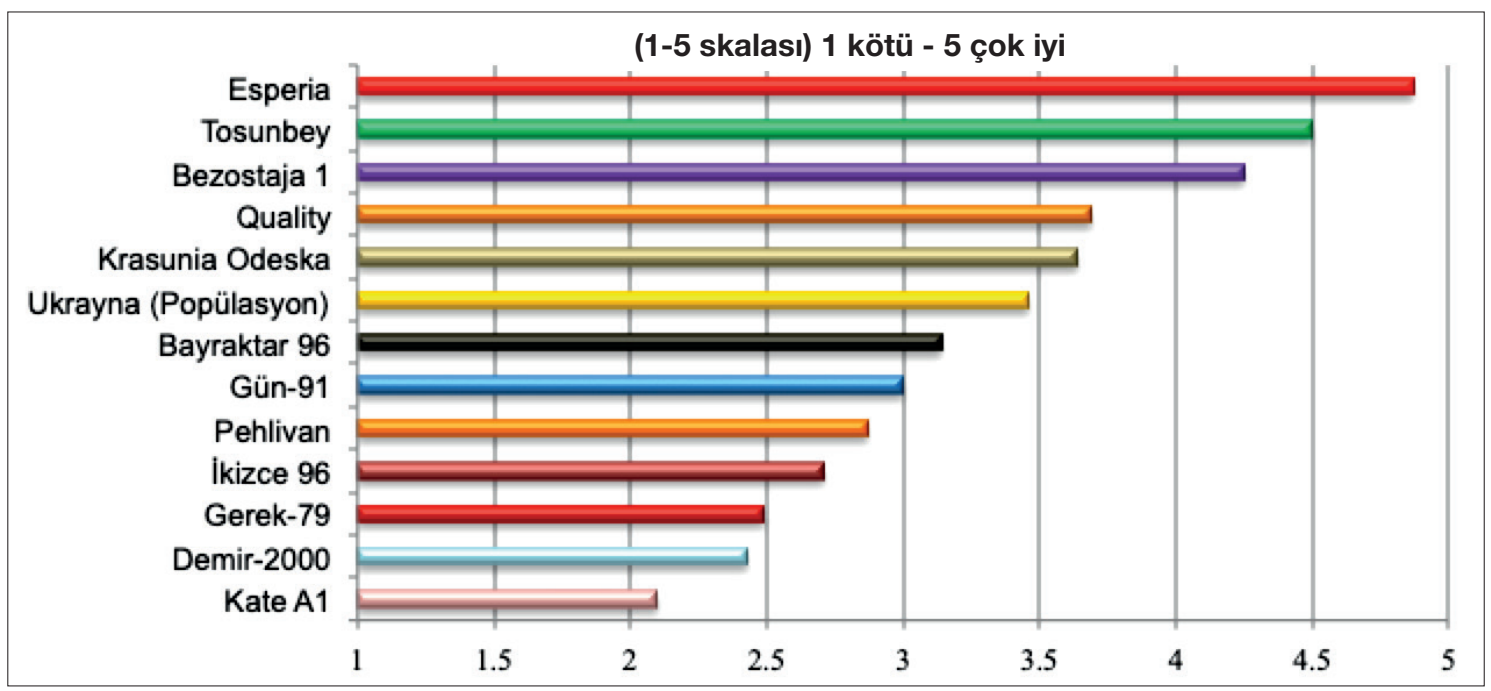

Șekil 2. Un fabrikalarının kullandıkları buğday çeșitleri hakkında görüșleri

Figure 2. Flour factories' opinions about wheat varieties they used 
Çizelge 8. Un fabrikalarının buğday çeșitlerini tanıma ve kullanma durumu

Table 8. The status of recognizing and using wheat varieties of flour factories

\begin{tabular}{lccc}
\hline \multirow{2}{*}{ Çeșit Adı } & $\begin{array}{c}\text { Tanınma oranı } \\
(\%)\end{array}$ & $\begin{array}{c}\text { Çeșidi Tanımasına Rağmen Un } \\
\text { Uretiminde Kullanmayanların Oranı (\%) }\end{array}$ & $\begin{array}{c}\text { Un Üretiminde Kullanma } \\
\text { Oranı (\%) }\end{array}$ \\
\cline { 2 - 4 } & $(\mathrm{A})$ & $(\mathrm{B})$ & $(\mathrm{A}-\mathrm{B})$ \\
\hline Bezostaja 1 & 100 & 3.3 & 96.7 \\
Tosunbey & 100 & 3.3 & 96.7 \\
Esperia & 100 & 6.7 & 93.3 \\
Ukrayna (Popülasyon) & 100 & 3.3 & 96.7 \\
Gerek-79 & 100 & 3.3 & 96.7 \\
Pehlivan & 93,3 & 13.3 & 80.0 \\
Gün-91 & 93,3 & 20.0 & 73.3 \\
Demir-2000 & 90,0 & 10.0 & 80.0 \\
Kate A1 & 83,3 & 6.7 & 76.6 \\
Krasunia odes'ka & 80,0 & 10.0 & 70.0 \\
Bayraktar 2000 & 80,0 & 13.3 & 66.7 \\
Quality & 70,0 & 3.3 & 66.7 \\
Ikizce 96 & 66,7 & 20.0 & 46.7 \\
Aldane & 36,7 & 10.0 & 26.7 \\
Ahmetağa & 26,7 & 16.7 & 10.0 \\
Lütfibey & 23,3 & 16.7 & 6.6 \\
Kenanbey & 10,0 & 10.0 & 0.0 \\
Eser & 6,7 & 0.0 & 6.7 \\
Seval & 0,0 & 0.0 & 0.0 \\
\hline
\end{tabular}

neticesinde, kalitesi en çok beğenilen buğday çeșidi Esperia olarak belirlenmiștir. Bunu Tosunbey, Bezostaja 1, Quality, Krasunia odes'ka çeșitleri izlemektedir.

Bezostaja 1, Tosunbey, Esperia, Ukrayna (popülasyon), ve Gerek-79 buğday çeșitleri, un fabrikalarının tamamı tarafından bilinmektedir. Pehlivan ve Gün-91 çeșitlerinin tanınma oranı \%93,3, Demir 2000'in ise \%90 olarak belirlenmiștir (Çizelge 8). Buğday çeșidini duymuș olmakla birlikte bu çeșidi un üretiminde hiçkullanmayanunfabrikalarıdabulunmaktadır. Bezostaja 1, Tosunbey, Ukrayna (Popülasyon) ve Gerek-79 çeșitleri fabrikaların tamamı tarafından bilinirken, \%96,7'si tarafından un üretiminde kullanılmıștır. Özelikle en çok tanınan çeșitleri "kullanmıyorum" șeklinde yanıtlayan un fabrikaları, genellikle çiftçiye buğday karșılığı un çeken küçük değirmenler olarak belirlenmiștir.

Fabrikaların en fazla kullandıkları buğday çeșitleri olan Bezostaja 1, Tosunbey, Esperia ve Ukrayna'nın fabrikalar tarafından yapılan kalite değerlendirilme skalasında da en yüksek puanları aldıkları görülmüștür (Çizelge 9). Bu sonuç sanayicinin üretimde yoğun olarak kullandığı buğday çeșitlerinin kalitelerinden de memnun olduğunu göstermektedir.

\section{Sonuç}

Tescil edilen ve üretim izni alarak üreticilerin kullanımına sunulan buğday çeșit sayılarının son yıllarda giderek arttığı görülmektedir. Yeni buğday çeșitlerinin geliștirilmesi, gen kaynağı olarak önemini korumakla birlikte, çok sayıda buğday çeșidinin var olmasının un sanayicileri tarafından istenilmeyen bir durum olduğu belirlenmiștir. Buğday çeșit sayılarının arttırımasının yerine; üreticiler tarafından halen yaygın olarak tercih edilen verimli ve kaliteli buğday çeșitlerin uygun ekolojilere göre yeterli tohumluk üretiminin ve dağıımının sağlanması için planlamaların yapılması daha uygun olacaktır. 
Çizelge 9. Un fabrikalarının buğday çeșitlerini kullanma durumu ve değerlendirme skalası Table 9. The usage status of wheat varieties and evaluation scale by flour factories

\begin{tabular}{lcc}
\hline Çeșit Adı & Un Üretiminde Kullanma Oranı (\%) & $\begin{array}{c}\text { Kalitatif Değerler } \\
(1-5 \text { skalası) }\end{array}$ \\
\hline Bezostaja 1 & 96.7 & 4.25 \\
Tosunbey & 96.7 & 4.50 \\
Esperia & 93.3 & 4.87 \\
Ukrayna (Popülasyon) & 96.7 & 3.46 \\
Gerek-79 & 96.7 & 2.49 \\
Pehlivan & 80.0 & 2.87 \\
Gün-91 & 73.3 & 3.00 \\
Demir-2000 & 80.0 & 2.43 \\
Kate A1 & 76.6 & 2.10 \\
Krasunia odes'ka & 70.0 & 3.64 \\
Bayraktar 96 & 66.7 & 3.14 \\
Quality & 66.7 & 3.69 \\
İkizce 96 & 46.7 & 2.71 \\
Aldane & 26.7 & 3.64 \\
Ahmetağa & 10.0 & 3.00 \\
Lütfibey & 6.6 & 3.33 \\
Eser & 6.7 & 3.33 \\
\hline
\end{tabular}

Buğday çeșitlerinden beklenilen verim ve kalite performansının alınamaması kamu ve özel sektör açısından, tescil için geçen 1013 yıllık süreç içerisinde yapılan ekonomik, teknolojik ve insan kaynağı yatıımlarının tam olarak geri döndürülememesi anlamına gelecektir. Yetiștirilen buğday çeșitlerinin sanayinin intiyaçlarına karșılamaya yönelik olarak geliștirilmesinin, tarıma dayalı sanayilerin girdi maliyetleri ve üreticinin geliri açısından önemlidir. Bu nedenle tarıma dayalı sanayilerle birlikte ilgili meslek ve kamu kurulușlarının bu alanda $\mathrm{Ar}-\mathrm{Ge}$ çalıșmaları yaparak sanayinin isteklerine göre buğday çeșitlerini ıslah etmesi ve üretiminin yaygınlaștırılması önem kazanmaktadır. Bu araștırma ile un sanayicilerinin buğday alıș fiyatını belirlemede en önemli kriterin; buğdayın süne emgi oranı olduğu belirlenmiștir. Buğday fiyatına etki eden diğer kriterler sırasıyla; buğdayın çeșidi, enerji değeri, gluten değeri, protein değeri ve hektolitresidir. Süne emgili buğday, un fabrikaları için ürettikleri unun kalitesini etkileyen en önemli faktördür. Buğdayın protein kalitesi daha çok çeșidin genetik yapısına bağlıdır. Bu nedenle protein kalitesi yüksek çeșitler un sanayisi tarafından öncelikle tercih edildiği için ve daha yüksek fiyatla ișlem görmektedir. Süne mücadelesi ile ilgili olarak çiftçi eğitimleri ve saha çalıșmalarının artarak devam ettirilmesi gerekmektedir.

\section{Kaynaklar}

Albayrak, A. \& Birsin, M. (2012). Ankara Tahıla Dayalı Sanayi Envanteri ve Strateji Raporu.

Arıkbay, C. (1993). Türkiye Gıda Sanayinde Teknolojik Yenilikleri İzleyememenin Maliyeti. Milli Prodüktivite Merkezi Yayınları No:484, Ankara.

Bayramoğlu, Z. (2007). Konya İlinde Tarıma Dayalı Sanayinin Yapısal Analizi (Yayınlanmamıș Doktora Tezi) Ankara Üniversitesi Fen Bilimleri Enstitüsü.

Bostancı, V., Cevher, C., Karabak, S., \& Demirel, Z.Y. (1999). Güneydoğu, Orta Güney ve Orta Kuzey Bölgelerinde Makarnalık Buğday Üreticilerinin Sosyo-Ekonomik Durumu. Orta Anadolu'da Hububat Tarımının Sorunları ve Çözüm Yolları Sempozyumu, 8-11 Haziran, Konya, Türkiye.

Burnett, V., \& Clarke S. (2002). Organic farming: Wheat production and marketing. Agriculture Notes. AG1075. ISSN 1329-8062

Cemalcılar, İ. (1982). Bisküvi Sanayiinin Sorunları. Türkiye 3. Gıda Kongresi. 14-16 Nisan 1982, Ankara. Gıda Teknolojisi Derneği Yayın No 4. 
Cörut, A. (1982). Makarna Sanayii Sorunları. Türkiye 3. Gıda Kongresi. 14-16 Nisan 1982, Ankara. Gıda Teknolojisi Derneği Yayın No 4.

Çoban, A. (2003). Tarıma Dayalı Sanayinin Beșerî ve Ekonomik Bakımdan Hızlı Değișim Sürecine Etkileri Üzerine Bir Örnek: Suluova, GÜ, Gazi Eğitim Fakültesi Dergisi 23 (3), 71-87.

Dizlek, H., \& İslamoğlu, M. (2010). Buğday Kitlesindeki Süne Emgi Oranının Belirlenmesinde Ülkemizde Sıklıkla Kullanılan Yöntemlerin Karșılaștırılması. U.Ü Ziraat Fakültesi Dergisi 24(1), 81-90.

Eker, B. (2007). Tarım Sanayi Etkileșimleri. http:// www.zmo.org.tr/etkinlikler/6tk05/ 07bulenteker

Ekși, A., Yurdakul, O., Emiroğlu, M., Güneș, E., Atamer, M., Topal, E., Tașdöğen, F. (2005). Gıda Sanayinde Yapısal Değișimler. http://www.zmo. org.tr/resimler/ekler/2547f5a44d87da3_ek.pdf

Günalp, E., Tolga T., \& Damla, Ö. (2002). Türkiye'de Un ve Unlu Mamuller Sanayinin Yeri Ve Önemi, Türkiye V. Tarım Ekonomisi Kongresi (sayfa 7076) 18-20 Eylül 2002, Erzurum, Türkiye.

Güneș, E. (1999). Bursa İlinde Sanayiye Yönelik Sözleșmeli Sebze Üreten Tarım İșletmelerinin ve Sebze İșleme Sanayinin Ekonomik Analizi (Yayınlanmamıș Doktora Tezi) Ankara Üniversitesi Fen Bilimleri Enstitüsü

Karkacıer, O. (2001). Tokat İli Tarıma Dayalı Sanayi Sektörünün Yapısal Analizi: Bir İnput-Output Analizi. Gaziosmanpașa Üniversitesi, Ziraat Fakültesi Yayınları No:57, Araștırma Serisi No: 18, Tokat.

Karakuș, S. (2017). Toprak Mahsulleri Ofisi'nin Üretici Kararları Üzerindeki Etkisi; Konya İli Çumra ilçesi Örneği, Yüksek Lisans Tezi, Selçuk Üniversitesi Fen Bilimleri Enstitüsü.

Kızıloğlu, S. (2004). Avrupa Birliği'ne Uyum Çerçevesinde Tarıma Dayalı Sanayinin Gelișmesinde Örgütlenmenin Rolü Ve Önemi. Türkiye VI. Tarım Ekonomisi Kongresi (sayfa 539-547).
Köksel, H., Sivri, D., Özboy, Ö., Bașman, A., \& Karacan, H., D. (2000). Hububat Laboratuvarı El Kitabı, Hacettepe Üniversitesi Mühendislik Fakültesi Yayınları, Yayın no: 47,106s.

Küçükçongar, M. (2001). Konya ili Un ve Unlu Mamuller Sanayiinin Yapısı, Sorunları, Çözüm Önerileri, Gıda Sanayi İçerisindeki Yeri (Basılmamıș Yüksek Lisans Tezi), Selçuk Üniversitesi Fen Bilimleri Enstitüsü Tarım Ekonomisi Ana Bilim Dalı

Marasalı, O.C. \& Karlı, B. (2005). Malatya İlindeki Tarıma Dayalı Sanayi İșletmelerinin Yapısı, Sorunları ve Çözüm Önerileri. GAP IV. Tarım Kongresi (sayfa 1444-1449), Cilt, 2, Harran Üniversitesi Ziraat Fakültesi, Șanlıurfa

Otteson, B.N., Merqoum, M., \& Ransom, J.K. (2008). Seeding rate and nitrogen management on milling and baking quality of hard red spring wheat genotypes. Crop Sci. 48, 749-755.

Özdemir, S. (2005). Tekirdağ İlinde Unlu Mamuller Sektöründe Faaliyet Gösteren İșletmelerin Pazarlama Yapılarının İncelenmesi. Trakya Üniversitesi Fen Bilimleri Enstitüsü (Yayımlanmamıș Yüksek Lisans Tezi) Tekirdağ

Rehber, E. (1997). Gıda Sanayiinde Üretici-Sanayi İlișkisi ve Sözleșmeli Tarım: Bursa Yöresi Örneği, U.Ü. Ziraat fakültesi Bilimsel Araștırmalar ve Incelemeler No:17, Bursa, 1997, 53s.

Tașcı, R. \& Bayramoğlu, Z. (2017). Arpa Çeșitlerinin Üretim, Pazarlama ve İșleme Açısından Önemi. Turkish Journal of Agriculture: Food Science and Technology 5(8), 923-934.

Tașcı, R., Karabak, S., Bolat, M., Pehlivan, A., Șanal, T., Acar, O., ... Albayrak, M. (2017) Ankara ilinde ekmek fırınlarının üretim yapısı ve ekmek israfı. Tarım Ekonomisi Araștırmaları Dergisi 3 (2017), 1-16.

TKB. (2009). " Ülkesel süne projesi sonuç raporu”, T.C. Tarım ve Köyișleri Bakanlığı Tarımsal Araștırmalar ve Politikalar Genel Müdürlüğü, Gıda Teknolojisi Araștırmaları. 